\title{
Radicalidade expressiva em Abílio-José Santos: uma obra poética fora do espaço da galeria, uma obra visual à margem do sistema editorial
}

\author{
Bruno Ministro \\ Centro de Literatura Portuguesa, Universidade de Coimbra
}

Resumo: Este artigo apresenta, numa primeira parte, uma contextualização da obra de Abílio-José Santos, sublinhando a diversidade das formas expressivas dos seus trabalhos e a exploração radical do material sígnico que aí se operacionaliza. A investigação centra-se, num segundo momento, na análise dos manifestos e textos de intervenção do autor, bem como em algumas das experiências de arte postal relacionadas com o projeto contestatário por ele desenhado. Interessado na crítica direta às esferas política, económica e aos sistemas de legitimação artística, Abílio-José Santos nunca descurou a contínua experimentação de novas estruturas poéticas, sendo possível encontrar nas suas obras uma politização da estética e uma crítica da estetização da política que se constrói por meio da própria prática artística.

Palavras-chave: poesia experimental, manifesto, materialidades da literatura, poética/política, Solidarte, artivismo, arte postal

Abstract: The first part of this article introduces to the work of the portuguese poet and designer Abilio-José Santos, highlighting its diversity of expressive forms and the radical exploration of the signs that are present in it. In a second instance, the article focuses on his manifestos and interventionist texts, as well as on some of his experiences with mail art that relate to the entirety of his subversive project. Interested in directly addressing politics, economics and the artistic legitimation systems, Abílio-José Santos never neglected the continuous experimentation with new poetic structures. Thus, it is possible to find in his works a politicisation of aesthetics and a critique of the aestheticisation of politics which is constructed through his artistic practice in itself.

Keywords: experimental poetry, manifest, materialities of literature, poetics/politics, Solidarte, artivism, mail art 
o artista era autodidacta e sócio correspondente $\mathrm{n}$ - 330 da sociedade nacional de belas artes. observava os homens, a natureza e as coisas, descobrindo, recriando, transfigurando, inventando... carecia, como qualquer indivíduo, de amor, de liberdade, de tempo, e de dinheiro para realizar-se. vivia para o estudo, a meditação, o recolhimento, o convívio, o diálogo, a renúncia. vivia para o trabalho. trabalhava com prazer até à dor, por imperativos humanos, fisiológicos e sociais. gravava o metal ou o linóleo como arranhando a sua carne, escrevia e pintava com tintas à base do próprio sangue."

(Abílio-José Santos em "edital”, texto para exposição na Galeria Alvarez, maio de 1968, Porto)

\section{Introdução}

Diz-se da segunda metade do século XX que não foi um tempo de manifestos. Só Abílio-José Santos (n. Maia, 1926-1992) escreveu quatro. E muitos mais textos panfletários se lhe somam: iconoclasmos verbais, biblioclasmos visuais, subversões viso-verbo-materiais. A sua proposta estética e política, situada no cruzamento entre visualidade e literariedade e convocando uma discussão sobre arte, sociedade e as suas interligações, permanece hoje tão atual quanto radical. O que aqui se pretende analisar é esse caráter comunicativo outro assente numa subversão crítica que se manifesta de forma simultânea numa expressividade radical (aquilo que o autor comunica) e numa radicalidade expressiva (como o comunica). Este desdobramento formal, servindo para substantivar o foco de leitura do artigo, não pode, conforme veremos, ser aplicado à obra de Abílio-José Santos, dada a síntese que opera entre forma e conteúdo, entre teoria e prática, entre estética e política, entre afirmação e negação.

Encontramos na globalidade das obras de Abílio-José Santos uma crítica feroz da mercantilização da arte e do consumismo da sociedade contemporânea, denúncias essas que se fazem acompanhar por uma recusa radical de todas as formas de poder e autoritarismo. O afastamento simultâneo da sua obra do mercado da arte e do sector editorial revela, não só um duplo desenquadramento (a sua obra não encontra espaço em 
nenhum dos campos), como também uma rejeição determinada (a sua obra não quer encontrar espaço em nenhum dos campos). Nos seus trabalhos a intervenção sócio-política e cultural realiza-se através da própria intervenção medial e material mas também por meio da disseminação alternativa dos artefactos produzidos. O seu radicalismo expressa-se assim numa poética afirmativa e contestatária que recusa a subjugação institucional e proclama mesmo a derrogação da arte como instituição.

\section{Contextualização de abílio na poesia experimental portuguesa (e consequente} desenquadramento)

A obra de Abílio-José Santos, que assina também somente com o nome próprio, constitui-se a partir das mais diversas formas expressivas exploratórias da relação entre palavra e imagem. A sua prática artística abarca campos que vão desde a pintura, gravura e desenho até à poesia, ${ }^{1}$ através de formas que são sempre desenvolvidas enquanto transgressora poética de cruzamento disciplinar. Deste modo, a sua obra tanto se inscreve no domínio da poesia concreta, como se estende à copy art e à poesia visual, aí operacionalizando a conjugação entre componentes verbais e elementos visuais nãolinguísticos, englobando ainda uma poesia de tipo linear, sempre com um fundo de experimentação do verso e da língua.

Sobre a ligação umbilical entre signo verbal e visual presente na obra de Abílio como no experimentalismo em geral, Severino Rodrigues assinalava já em $1959^{2}$ o caráter aglutinador da obra de Abílio no cruzamento entre expressões poética e plástica:

Aqui, falando de Abílio, diria melhor 'pintar-se': ou talvez pôr em pintura os seus versos, por ser aquela a plasticização dos devaneios poéticos que escassamente o verbo the poderá traduzir na forma condigna a que aspira e o título das suas composições manifestamente revela. / Poeta que pinta, conceda-se então. (Rodrigues 1959: s.p.)

Anos mais tarde, quando publica o seu primeiro livro, O Voo do Morcego (1962), obra breve constituída por dezoito poemas, o diálogo entre artes visuais e poesia prossegue os seus processos de intersemiose. Não se trata ainda de uma fusão entre os sistemas de signos, embora se revele já aí uma faceta premonitória da radicalização intersígnica que ocupará um lugar fundamental na sua obra. É ainda na década de 1960 que Abílio inicia a 
conceção de obras que promovem a emergência de sentido por duas vias simultâneas: signo verbal e visual surgem unificados numa pesquisa exploratória da dimensão plástica da linguagem. No mesmo ano em que publica o folheto Lidança (1968), a sua primeira obra de caráter concretista, ${ }^{3}$ é também convidado a participar em Arlington Quadro / Quadlog, exposição coletiva realizada em Gloucestershire que reuniu poetas experimentais e concretos portugueses e britânicos, fruto do diálogo entre os artistas e grupos de Portugal, Inglaterra e Escócia. Trabalhos seus serão também incluídos na Antologia da Poesia Concreta em Portugal, publicada em 1973 por E. M. de Melo e Castro e José-Alberto Marques, e integrará a representação portuguesa à XIV Bienal de S. Paulo, realizada em 1977.

O caráter problematizador de género literário que encontramos na obra de Abílio enquadra-a, portanto, nas principais linhas do experimentalismo literário, cujo esforço de teorização, em Portugal, foi desenvolvido pelos próprios poetas e que tem maior destaque nos artigos, ensaios e livros redigidos por Ana Hatherly e E. M. de Melo e Castro. ${ }^{4}$ A este enquadramento material da obra de Abílio corresponde, contudo, um desenquadramento social do seu autor, dado que o artista, embora tenha participado em algumas das iniciativas promovidas pelos poetas experimentais, permaneceu sempre na periferia das suas principais linhas de atuação.

Rui Torres, que deteta um caráter anunciador da eclosão da poesia experimental portuguesa na "abordagem minimalista e repetitiva de Abílio-José Santos em $O$ Voo do Morcego" (Torres 2014: 11), salienta o facto de a relação que o artista estabeleceu com os outros poetas da poesia experimental portuguesa ser uma relação fluida (Torres / Ministro 2016), de participação em algumas das suas atividades mas de não adesão aos textos teóricos que aqueles autores foram publicando ao longo dos anos. A sua posição na história da poesia experimental em Portugal é, ainda na esteira de Torres, um pouco semelhante à ocupada por Alberto Pimenta, poeta que, acerca de Abílio, refere o seguinte:

trabalhou sempre à margem do grupo de poetas concretos e do seu sistema teórico, que recusa. para ele, todo o fundamento epistemológico é repressivo: nesse sentido é o mais consequente de todos. a sua produção rebenta em colagens corrosivas, ou inventa 'cirurgias de forma', ou espaços nos quais as letras entram como invasores dum outro mundo. o seu mundo é o erotismo das formas condenadas à mudança, à 'lidança', ao trabalho. O ZERO NÃO É INÓCUO! COM O ZERO OPERO COM O UM! trabalho e liberdade, trabalho e(m) liberdade. (Pimenta 1988: 149) 
A caraterização que faz de Abílio está envolta - ao estilo de Pimenta - em diversos jogos de palavras com os títulos de algumas das suas principais obras em papel (Fotocirurgiando, Lidança, Trabalho/Liberdade, etc.), com destaque para a sua recusa da subserviência a qualquer sistema (teórico, refere-se, mas também político, artístico e técnico, podemos acrescentar) e, mais importante ainda, colocando a tónica na atividade criativa enquanto meio de produção de "formas condenadas à mudança, à 'lidança', ao trabalho." Se a mudança (no sentido de transformação), está sempre presente nas suas obras, também o conceito de trabalho é, pois, um elemento central em Abílio-José Santos. Primeiro, porque a sua prática artística, num gesto que não está isolado no cenário da arte contemporânea, opera um descentramento da obra enquanto resultado para a obra enquanto processo. Em segundo lugar porque, neste âmbito, o trabalho de criação não apresenta, na leitura realizada a partir dos diversos statements do autor e daquilo que as suas obras comunicam, diferenças significativas em relação ao trabalho enquanto fator de produção económica, antes os radicalizam (i.e. desenraízam, poder-se-ia dizer, indo precisamente à raíz de "radical") ao esbater a diferença clássica entre trabalho criativo/intelectual (ergoni, opus) e trabalho braçal (ponosi, labor). ${ }^{5}$ A obra de Abílio, ao convocar uma esfera política maior para a sua prática artística, comunica com premissas que Ihe são mais ou menos próximas, em termos temporais e ideológicos, como as máximas "A poesia deve ser feita por todos" (Conde de Lautréamont) e "Cada homem, um artista" (Joseph Beuys).

Estando representado nas principais antologias da poesia experimental portuguesa e em vários catálogos de exposições nacionais e internacionais, ${ }^{6}$ a sua poesia não foi publicada nos circuitos convencionais e, também por isso, foi sempre de difícil acesso. Pouco conhecida e reconhecida, têm sido escassos os estudos realizados sobre o autor. O silêncio a que a obra de Abílio foi exposta pela crítica e pela academia não é de todo condizente com a extensão da sua obra. Só no que diz respeito a exposições, o artista participou em perto de uma centena de iniciativas, entre as quais se incluem 24 exposições individuais, tendo ainda sido incluídos trabalhos seus em perto de outra centena de mostras de arte postal na Europa, na América e na Ásia. ${ }^{7}$ 
Em Portugal, para além das exposições de arte postal em que participa ou que $\operatorname{organiza}^{8}$, realiza diversas exposições individuais entre 1959 e 1992. Estas exposições têm lugar sobretudo nas cidades do Porto, Maia e Aveiro, percorrendo um circuito de espaços alternativos e de vanguarda como a Galeria Divulgação (1959), Sala da Sereia (1962), Galeria Borges (1964; 1965; 1966), Galeria Árvore (1965; 1969; 1970; 1980; 1992), Galeria Alvarez (1968) e Galeria Abel Salazar (1975), sendo que, em Lisboa, expõe por duas vezes, primeiro na Galeria Ulmeiro (1970) e depois no Atelier 15 (1985). Com a Galeria Dominguez Alvarez, de Jaime Isidoro, Abílio colaborou também de forma mais prolongada, tendo sido o responsável pelo seu atelier de gravura a partir de $1965 .{ }^{9}$ Abílio realiza ainda diversas exposições fora do espaço das galerias, nomeadamente em escolas da Maia e do Porto, o que ilustra bem, como colocado por Eunice Ribeiro, o seu "percurso de propícia marginalidade" (Ribeiro 2014: 117), de igual forma fazendo ressaltar a sua procura de espaços alternativos de comunicação. Isto engloba também as suas publicações, sempre editadas com os seus próprios meios, produzidas, portanto, fora do sistema editorial e disseminadas à margem do circuito de distribuição comercial.

Após publicação do seu primeiro livro, O Voo do Morcego (1962), e do seu primeiro folheto, Lidança (1968), já aqui referidos, Abílio-José Santos inicia um período intenso de produção de publicações experimentais por vezes próximas do domínio da poesia concreta, outras da poesia visual e ainda daquilo que o próprio denomina como textos de intervenção ou textos panfletários, neste caso assumindo uma pluralidade de formas díspares. Algumas obras deste tipo serão analisadas com detalhe neste artigo, sendo desde já importante clarificar que as missivas que elas encerram, não obstante o seu caráter comunicativo de interpelação direta, não se furtam a perseguir complexos níveis de experimentação técnica e estética. É também por isso que, como constatam Fátima Lambert e João Fernandes, o seu trabalho se configura como "um caso único no contexto da arte e da poesia portuguesas, protagonizando o exemplo de uma criação artística underground, radical e implacável" (Lambert/ Fernandes 2001: 29), isto tendo em consideração que as publicações de Abílio "aliavam uma rara intuição gráfica à assunção orgulhosa da sua marginalidade e efemeridade" (ibidem). 


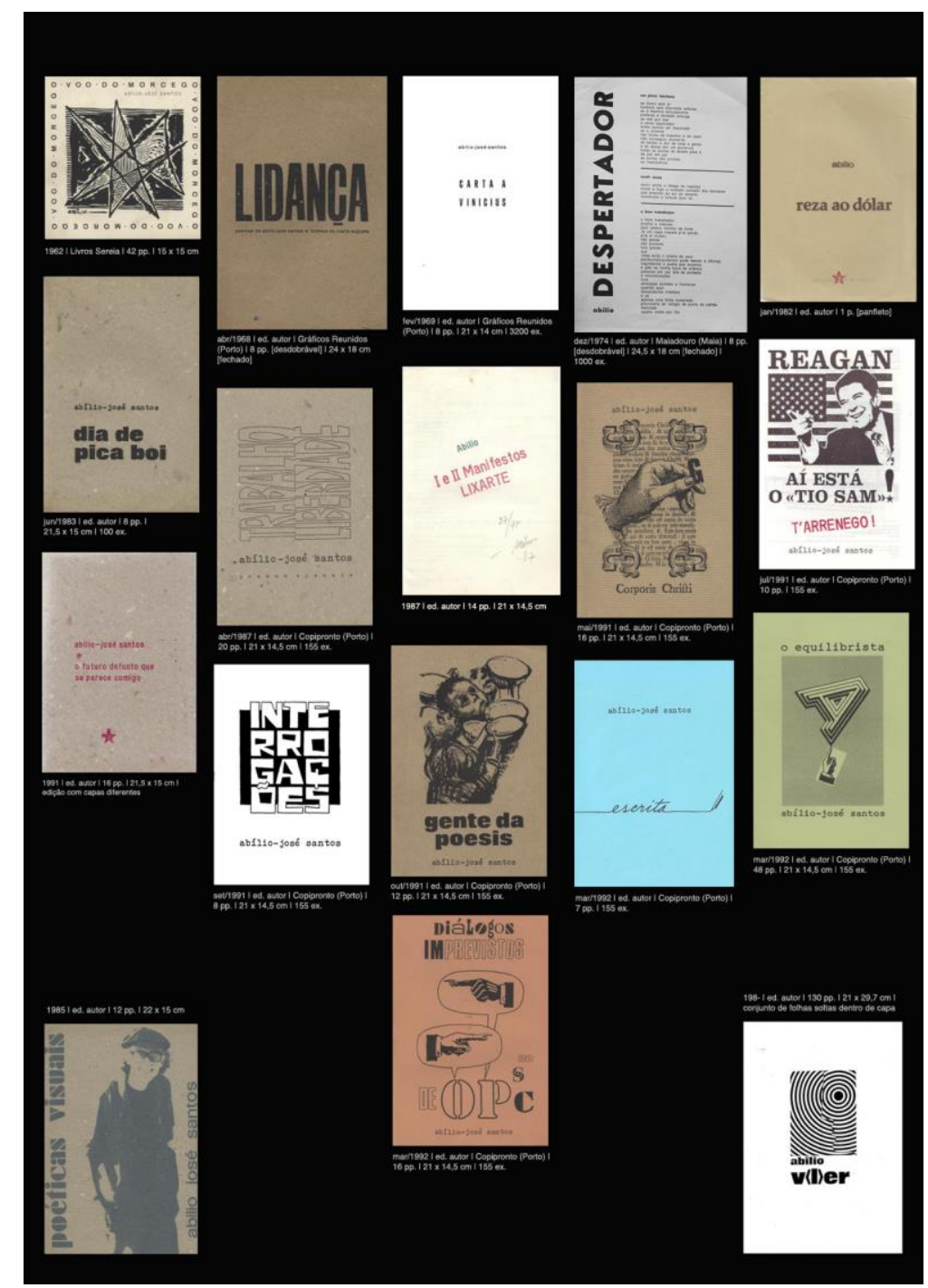

Figura 1: Capas de algumas das publicações experimentais de Abílio.

Abílio concebeu a sua obra escrita ${ }^{10}$ com recurso a vários tipos de dispositivos à sua disposição, constituindo formalmente as suas publicações sob a forma de brochuras, folhetos e panfletos desdobráveis (fig. 1), por exemplo. O artista - ao mesmo tempo autor e editor/produtor - cria as suas obras a partir da apropriação dos formatos standardizados e perecíveis da comunicação de massas, movendo-se no sentido de uma "produção pretensamente efémera" (Lambert 2003: s.p.) que, em realidade, não o é - perdura no tempo, ainda que ocupando lugares periféricos, em decomposição e metamorfose. ${ }^{11}$ As obras impressas de Abílio, quer as que fazem uso da tecnologia offset quer aquelas que recorrem à fotocópia como meio facilitador da reprodução e distribuição, circulam sobretudo em círculos restritos, nomeadamente através da rede de arte postal, sendo na 
sua maioria publicações com poucas páginas e de tiragens reduzidas. De tão esquiva, a obra de Abílio chega a aproximar-se, em alguns momentos, de uma proposta de destruição da arte. Não sem generosas doses de insolente sátira, a anulação total do valor da arte está presente por exemplo nos versos "o que desenho escrevo / gravo corto e colo / pode amanhã não valer nada / mas as embalagens / também não", de O futuro defunto que se parece comigo (1983; 1991), ou no título frontalmente autodestrutivo da coleção 5 postais pra queimar (s.d.).

\section{Materiais, intervenções e intervenções materiais}

A radical exploração intersígnica que Abílio-José Santos desenvolve nos seus trabalhos expressa-se através de um vasto conjunto de técnicas e suportes materiais. A apropriação que faz de fontes materiais previamente existentes - como recortes de imprensa, ou, com especial relevo na sua obra, materiais pobres que poderiam ser considerados meros detritos - enquadra-se perfeitamente na linha de subversão contínua dos discursos que encontramos na poética de Abílio. O próprio autor reflete sobre esta proposta de intervenção pela "reciclagem" quando, no primeiro dos seus manifestos com o título "lixarte", 12 de julho de 1985, sumaria o seu posicionamento no lema "a arte como lixo / o lixo como arte" (Santos 1987a: s.p.). Esta proposição está presente em toda a sua obra através do frequente desvio dos materiais de base e consequente emergência de discursos outros, portanto em rutura com os discursos hegemónicos representados pela "máfia estabelecida \& dominante", expressão que Abílio usa, ainda no mesmo texto, para nomear o conjunto de críticos, júris, galerias, museus/mausoléus, artistas amestrados, (auto)mecenas, entre outros. Se este manifesto acaba com um "viva dada", incorporando o espírito disruptivo daquele movimento enquanto crítica direta ao mundo da arte, não é menos expressiva a afirmação que abre o manifesto: "se a poesia ainda não é feita por todos / o lixo já / há lixo em toda a parte / desde a viela mais sórdida ao palácio de s. bento" (ibidem). Agentes artísticos e políticos são alvo simultâneo das palavras do artista, sendo que ambos são considerados resultado dos mesmos processos de dominação social. Muito marcada pelo humor, a atitude crítica de Abílio chega mesmo a adquirir uma linguagem violenta: “Abaixo a prostituição artística (e não só)! Abaixo todos os chulos e parasitas!", proclama no 
seu (COLAGE)Manifesto Vermelho, analisado com detalhe adiante. Criticar o sistema da arte, em Abílio, é sempre criticar as estruturas políticas. O inverso também se verifica, embora haja momentos em que o artista distingue uma e outra esfera:

é claro que os tais ensaístas/críticos só os aturo quando me quero divertir ou para alimentar baterias... mas dos tais políticos sofro todos os malefícios das governanças deles tão violentamente como os tipos que os elegeram livremente ou aconselhados por algum representante divino ou capitalista coercivos... (Santos 1985a: 107)

A crítica política é particularmente aguerrida quando no manifesto "lixarte/2", com data de setembro de 1985, se sugere que "o lixo é útil / quando reciclado", embora, acrescenta o autor, "há lixo / político / sem reciclagem possível" (Santos 1987b: s.p.). Também numa carta que Abílio-José Santos escreveu a Mauricio Guerrero um ano antes de redigir os manifestos "lixarte" podemos encontrar a afirmação desta procura de uma "redenção do lixo" através da "subversão da arte", servindo inclusive as palavras do artista enquanto statement sobre os seus processos criativos:

Artisticamente, desde a década de 50 [...] que recuso os chamados materiais nobres. Em vez deles utilizo normalmente o lixo da sociedade de consumo e sucata... Tudo me serve para motivar, incorporar e/ou construir trabalhos de Desenho, Pintura, Gravura, Escultura e principalmente Colagem. Ao utilizar coisas consideradas inúteis, desprezadas, como embalagens de papel, cartão, plástico ou metal... trapos, sapatos, brinquedos, carteiras de senhora, jornais, revistas,... peças de máquinas, de ferramentas ou de bicicletas... etc., atinjo três objectivos:

- a redenção do lixo;

- a subversão da Arte, pela íntima ligação entre a obra de Arte clássica e os materiais tradicionais;

- e o realismo máximo! pois quando entra em certos trabalhos meus um sapato velho, roto e enlameado, não o represento pela imagem desenhada, pintada, gravada, esculpida, fotografada ou impressa! - apresento-o. (Santos 1984: 1-2)

Porém, na obra do artista não é só o artefacto industrial que serve de matéria pronta para apropriar e desviar - ao estilo do ready-made de Duchamp, artista que Abílio convoca várias vezes nas suas obras e testemunhos, ${ }^{13}$ da arte bruta de Jean Dubuffet ou do détournement dos letristas e situacionistas -, também os elementos da natureza são convocados na sua obra. Além da paródia ao "realismo mágico" na sua proposta de um 
"realismo máximo", é o próprio artista quem afirma, em texto já antes citado, que "a poesia visual está em toda a parte!... pronta-a-ler! feita por todos e pela natureza (cá por mim não me custa nada acreditar que se existisse algum deus também era capaz de dar uma ajuda)!... só é pena se ainda não é lida por todos livremente!" (Santos 1985a: 108). Ao modo de Alberto Caeiro, como evidencia Eunice Ribeiro (2014), testemunha o artista: "os poetas que mais admiro são o pão, a água, o olhar das crianças, uns seios de mulher, o vagabundear pelo porto, embalagens esmagadas pelo rodado dos carros contra o piso das ruas, o sol, a chuva, as árvores." (Santos, 1985a: 108). Há evidentemente um toque de Álvaro de Campos também aqui, em particular na friç̧ão dos rodados dos carros que esmagam embalagens contra ao chão.

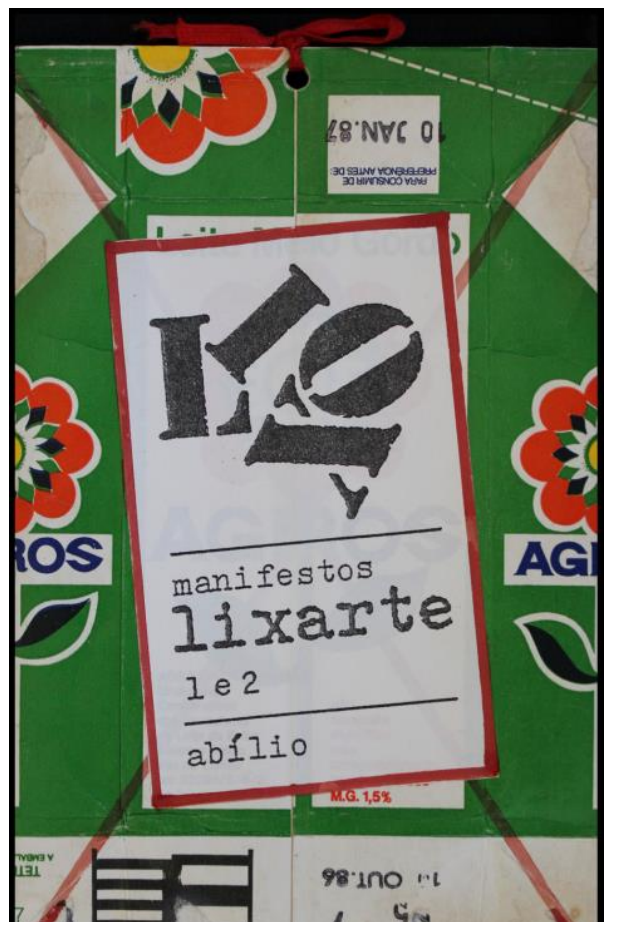

Figura 2: Manifestos “lixarte" 1 e 2 (frente), 1986. Reproduzido com permissão.

Embalagens esmagadas também as há na obra de Abílio, não apenas como imagem convocada, como acima exemplificado, mas antes enquanto objeto materializado de facto, “objeto artistificado" chamar-Ihe-ia o autor (Santos 1968: s.p). Em 1986, o artista produziu uma versão dos manifestos "lixarte"14 que distribuiu dentro de embalagens tetra pack espalmadas (fig. 2), com furo e fita no topo para servir de fecho. Uma fotocópia colada no pacote com composição visual em torno da palavra "lixo" serve de "capa" a esta 
"publicação". Por baixo da fotocópia e na "contracapa", uma cruz desenhada com marcador, traçada na diagonal, de ponta a ponta do pacote, anula o objeto pelo cancelamento da sua objetualidade primária. Esta rasura e rejeição do objeto original - mas ainda presença, rasto $^{15}$ - articula-se, portanto, em duas dimensões correlacionadas: desprovido da sua função original (até porque já não contém leite, o produto já foi consumido e deixou à embalagem uma existência irrelevante, que já não serve), o pacote é refuncionalizado deixando de ser um pacote de leite para passar a ser um invólucro de textos; para além dessa desfuncionalização e ressemantização, como atrás foi dito, o próprio ato de apropriação e negação está vinculado ao gesto de rasura do objeto - o gesto duplicado de o espalmar e rasurar fá-lo deixar de ser o objeto original que fora porque aplana e nega o objeto tridimensional, roubando-Ihe assim o seu caráter de contentor e substituindo o seu interior por outro conteúdo.

Outras embalagens são expressivamente usadas em obras como a série de objetos $A r$ Bento, ${ }^{16}$ humorísticos produtos de consumo massivo realizados a partir de pacotes de leite, embalagens de queijo e outras; ou Totem (fig. 3), conjunto de 9 pacotes de leite organizados em bloco $3 \times 3$ com cinta elástica numa paródia à sacralização da arte e à religiosidade do consumismo, obra que fez parte da exposição LIXARTE, realizada na Galeria Árvore, no Porto, de março a abril de 1992, naquela que foi a última exposição individual do artista, já no ano do seu falecimento.

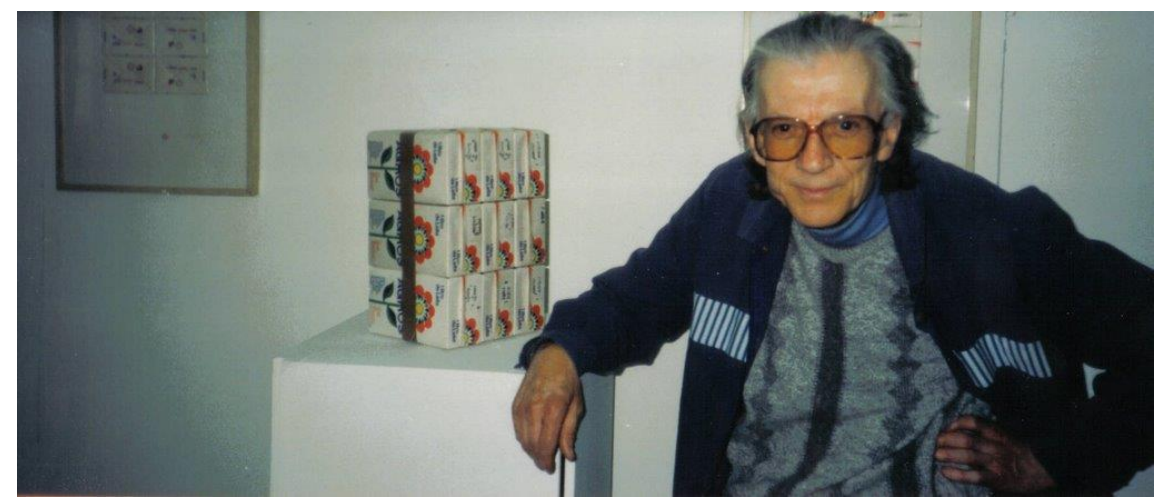

Figura 3: Abílio junto a Totem na exposição LIXARTE, Galeria Árvore, 1992. Fotografia de César Figueiredo. Reproduzido com permissão. 
No cuidado artigo "Abílio: As manufacturas da escrita", Eunice Ribeiro, a propósito de $E s c r i t{ }^{17}$ de Abílio, nomeia como dimensão central na sua obra "[a] sedução pelo artesanato, pela manufactura, a ideia de uma escrita-gesto dotada de um carácter processual e exigindo o total envolvimento do sujeito" (Ribeiro, 2014: 118), sendo que esta natureza de propensão "artesanal", desde logo destacada no título do artigo de Ribeiro, é também mencionada por Severino Rodrigues quando refere positivamente o caráter amador convocado pela obra do artista: "Abílio não é um pintor profissional e oxalá nunca o venha a ser, pois toda a sua originalidade de artista reside precisamente no saudável amadorismo que o impede de cristalizar" (Rodrigues, 1959: s.p.).

A obra de Abílio é já, em si mesma, uma afirmação do esbatimento da diferenciação convencionada entre arte popular e arte erudita, e, sobretudo, uma insurreição contra os seus capitais simbólicos - pejorativos em relação ao primeiro, laudatórios em relação ao segundo - postura estético-sociológica que materializa através do seu empenho total na subversão do binómio que opõe baixa cultura a alta cultura. Por outro lado, embora se possa dizer que a sua obra nasce de um engajamento social e político, a verdade é que ela não é subsidiária de nenhuma fação ideológica no sentido em que a sua obra não surge como ferramenta para nenhuma intervenção, ela é a intervenção. A sua obra nasce de um compromisso mas não é nem está comprometida. E esse compromisso não resulta de um esforço nem é forçada, é, isso sim, algo que surge de forma muito natural. É curioso, até, como os poucos autores que escreveram sobre a sua obra empregam frequentemente termos próximos a esta ideia de naturalidade (expressões destacadas por grifos meus): Severino Rodrigues destaca na obra de Abílio uma "sinceridade" que está "não raras ocasiões ausente de obras destinadas ao comércio ganha-pão" (Rodrigues 1959: s.p.); Cristina de Azevedo, reportando-se à exposição Poéticas visuais (1985), realizada no Atelier 15, em Lisboa, considera que os trabalhos do artista se revelam através de "combinações simples e claras com as quais Abílio Santos joga o seu 'feeling' da expressão plástica das formas." (Azevedo 1985: s.p.); Óscar Faria, a propósito da inclusão de obras do autor na exposição Porto 60/70: Os artistas e a cidade (2001), argumenta que as obras de Abílio são atravessadas de forma transversal por "doses elevadas de humor e de uma crítica espontânea e terrivelmente eficaz" (Faria 2001: s.p.); por seu turno, Fátima Lambert fala de 
uma "frontalidade exaustiva" que faz transparecer nas obras do autor "a exemplaridade de um produto genuíno e underground." (Lambert 2003: s.p.).

A obra de Abílio, no seu conjunto, nasce da frontal espontaneidade de um gesto genuíno de subversão que nele está interiorizado - "sou desenhador de profissão e autodidacta insurrecto por índole" (Santos 1985b: s.p.). De forma arriscada e radical, a reformulação que faz dos discursos de poder é realizada através do próprio exercício de arranjo dos materiais do poema, muitas vezes apropriando e transformando (transgredindo) os objetos ao produzir um novo contexto para os receber. Relocalizados os significantes, fazse com que os significados expressem, não raras vezes, o contrário daquilo que significavam no contexto de origem. O signo existe no espaço de transição, transmissão, transgressão.

\section{Margens locais e alternativas globais: Manifestos e textos de intervenção}

Abílio publica e expõe à margem do sistema literário e da arte, o que não quer dizer que não encontremos obras suas nas primeiras edições de alguns dos eventos mais impactantes do espaço artístico e cultural português contemporâneo. São disso exemplo as Bienais Internacionais de Arte de Vila Nova de Cerveira organizadas por Jaime Isidoro (Abílio participa nas quatro primeiras edições, entre 1978 e 1984) ou os Encontros Internacionais de Arte, com direção de Egídio Álvaro e Jaime Isidoro, realizados entre 1974 e 1977 (em cujas II, III e IV edições são expostos trabalhos do artista). Nos Terceiros Encontros Internacionais de Arte, realizados na Póvoa de Varzim entre 7 e 17 de agosto de 1976, Abílio-José Santos integra a exposição Presença, descrita como uma "exposição aberta" na qual "cada participante pode apresentar as suas obras em inteira liberdade", nesse sentido constituída enquanto "exposição inteiramente estruturada e feita pelos expositores [...] uma exposição/encontro e uma exposição/diálogo." (Álvaro 1977a: 22). O diálogo mantido neste encontro passou pela mostra de América, colagem audiovisual coletiva do Grupo Vermelho, ${ }^{18}$ patente na exposição apenas a partir das $23 \mathrm{~h}$ do dia $14,{ }^{19}$ portanto já bastante perto do final do evento, foi acompanhada pela divulgação do (COLAGE)Manifesto Vermelho, um "demolidor manifesto performativo-dadá" (Dias 2016: 408) no qual Abílio, ${ }^{20}$ em tomada de posição iconoclasta e derrogatória da arte enquanto instituição, "defende o nascimento da arte moderna com o dadaísmo, definindo enquanto arte apenas o que é feito 
ou lido ao nível da criação, não o produto e o que se afirma alheio aos circuitos da critica e da subjugação institucional." (Metello 2009: 249). A obra América, baseada num conto de Michael Gold e constituída por um painel com textos associados a colagem e banda sonora, é apresentada presencialmente por Abílio - fazendo uso dos espaços abertos de debate que foram privilegiados nos Encontros - na noite do dia 14 em intervenção na qual o artista "explicou as dificuldades económicas encontradas pelo Grupo na concretização do trabalho e descreveu parte da colagem." (Álvaro 1977b: 59). Egídio Álvaro refere ainda, em súmula descritiva dos debates, que o trabalho apresentado "foi muito controverso" (ibidem). Ou não se tratasse de um trabalho criado para gerar debate.

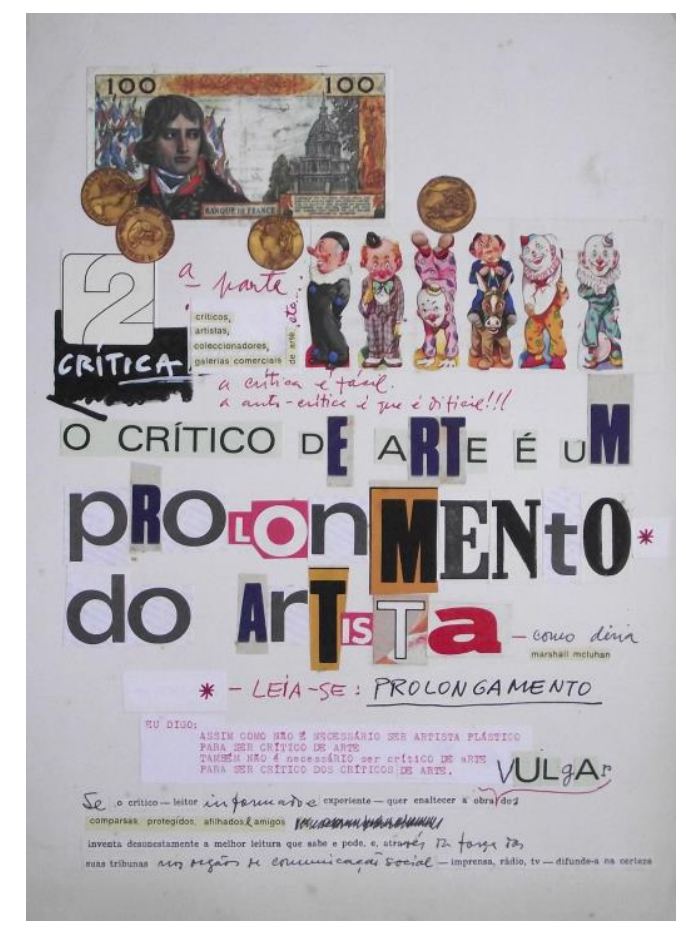

Figura 4: Segunda folha de (COLAGE)Manifesto Vermelho, 1976. Reproduzido com permissão.

Elaborado com predominância de técnicas de colagem e caligrafia, (COLAGE)Manifesto Vermelho (1976, fig. 4) é constituído por oito folhas de tamanho DIN A4, encontrando-se dividido em quatro secções: "arte" (1. a parte), "crítica" (2.a parte), "viva o dadaísmo" (3. - parte), bem como por uma secção final intitulada "e um desafio à prova de provocações, calúnias \& outras 'coisas' 'democráticas \& pluralistas'". Além das letras garrafais cuja estética denuncia a proveniência dos materiais de jornais e revistas, tudo o 
que no manifesto é reproduzido em letra mecânica tipográfica é recorte de dois textos anteriores de Abílio, "arte e liberdade" (s.d. [197-]) e "manifesto à cidade" (1974).

O facto de também a inscrição caligráfica assumir no manifesto um lugar de destaque - nas formas oscilantes da letra em cor, tamanho e desenho -, contribui fortemente para a conceção da escrita de Abílio enquanto "grafia corporal onde se descobre a relação afectiva do homem com o traço que assina - traço caligráfico ou impresso mas sempre modelado por um sujeito." (Ribeiro 2014: 124). A mão que desenha a escrita é a mesma mão que recorta e cola, remetendo para um "gesto arcaico do recortar-colar" (Compagnon 1996: 12), no qual o texto encontra definição na redefinição do próprio conceito de texto: "o texto é a prática do papel" (idem: 11), isto porque "[r]ecorte e colagem são as experiências fundamentais com o papel, das quais leitura e escrita não são senão formas derivadas, transitórias, efêmeras." (ibidem).

É na transitoriedade dessa escrita que é também ação e, por isso, gesto performativo propositadamente efémero e derivativo (sempre em processo), que se joga a construção do discurso crítico de Abílio-José Santos. Um discurso que é texto mas também imagem - é, diríamos, um texto verbo-visual -, sendo que também as imagens que fazem parte da colagem são recortadas de outros contextos prévios à obra. Na fenda que se abre entre o lugar do signo original em contexto e o seu novo lugar sígnico contextual, deparamo-nos com a diferença na repetição, naquele que é ao mesmo tempo sulco que separa e material condutor que une. Afirma-se por isso, com Jacques Derrida a propósito da colagem num livro que é ele mesmo uma monumental colagem (citação recortada de Derrida através do recorte que fez Marjorie Perloff num dos livros mais incisivos sobre poéticas outras):

That the sign detaches itself, that signifies of course that one cuts it out of its place of emission or from its natural relation; but the separation is never perfect, the difference never consummated. The bleeding detachment is also - repetition - delegation, commission, delay, relay. Adherence. The detached remains stuck by the glue of difference (Derrida apud Perloff 2003: 75)

É o corte mas é também a cola que separa o lugar de emissão originário do seu novo espaço de enunciação atualizado, acumulando signos, renegociando-os, fazendo com que a hierarquia dê lugar à parataxe, como afirma Perloff (ibidem) ao problematizar a colagem na 
esteira de estudos de Rosalind Krauss (The Originality of the Avant-Garde) e que, por seu turno, na cadeia incessante da colagem e remistura crítica, Craig Dworkin (2003) tomará para a sua reflexão. Também aqui neste artigo, experiencie-se no processo, exercício de colagem e significação em camadas na rede citacional.

Todo o manifesto é um ato performativo: o enunciado que produz posiciona-se no mundo de maneira a agir sobre ele. O manifesto de Abílio-José Santos apresenta-se como um texto radicalmente performativo na medida em que, em primeiro lugar, tudo o que nele surge em letra mecânica é apropriação direta (desvio e ressignificação) de materiais anteriores aqui renovados pela colagem no novo contexto expressivo; em segundo lugar, de maneira articulada com o ponto anterior, tudo o que nele é manuscrito constitui uma derivação nos interstícios do texto, nas fissuras abertas pelo corte, abrindo lugar para a expressividade do novo ato de escrita (e sua temporalidade histórica) e para todos os atos de leitura que, recortando também eu as palavras do autor de um dos textos que ele recorta, "o leitor for capaz de fazer sem limitações, livremente, metamorfoseando, descobrindo, inventando, manipulando, experimentando, encontrando..." (Santos s.d. [197]: s.p.).

Na primeira das seç̧ões do manifesto, o autor denuncia a subjugação da arte face aos interesses económicos ao reproduzir, em colagem direta e fotocópia, várias moedas e notas, enquanto no apartado textual se afirma que "a arte não existe. o metro existe. em sèvres. frança." ${ }^{21}$ Alude o autor à barra de liga metálica depositada no Instituto Internacional de Pesos e Medidas, em Sèvres, que foi usada até 1983 como medida padrão do metro. Ao caráter especial e reservado desta barra, aqui usada de forma simbólica, Abílio contrapõe aquilo que defende ser o caráter universal e aberto da arte: "tudo é arte quando feito ou lido a nível criador" (sentença por duas vezes enunciada no manifesto), sendo que "o nível criador é: a) potencialmente atingível por todos os cidadãos; b) colectivamente atingido pelo povo; c) individualmente atingido pelos artistas." 22 E os artistas, esses, afirma de seguida já numa diferente tira de papel datiloscrita, "estão no povo. / o povo está nos artistas.". A proposta de socialização da arte será tornada ainda mais explícita na reflexão que tem lugar na segunda parte, onde, em determinado passo, se proclama: 
o artista revolucionário ${ }^{23}$ pode e deve ser útil à cidade, por conseguinte ao povo, exercendo, no momento histórico que vivemos, acções culturais pedagógicas, urgentes e necessárias à transformação - saneamento - de todo o sistema viciado - corrupto e corruptor - de produção e fruição artísticas áudio-visuais e o respectivo mercado. (Santos 1976: s.p.)

Lançando uma pergunta retórica - "mesmo os artistas mais revolucionários fizeram alguma coisa comparada com o que fizeram os mais conscientes operários e camponeses???" -, Abílio declara: "Aprendamos com os operários e os camponeses a defender os nossos direitos revolucionariamente! Não queiramos manter privilégios que nos envergonham!". ${ }^{24}$ Com efeito, além do enfrentamento da sociedade de classes, a segunda parte deste manifesto consiste numa denúncia feroz dos críticos de arte, onde não faltam instituições e nomes concretos, repetindo-se as acusações (e respetivas nomeações) que também encontramos noutros textos do autor. Isto porque, lendo esta repetição até como apropriação direta por via do recorte e colagem, "há artistas falhados que são críticos. / há críticos falhados que são artistas?", percetivelmente recortados de um exemplar do seu "manifesto à cidade" (1974).

Com efeito, o seu "manifesto à cidade", ${ }^{25}$ datado de 1 de maio de 1974, dialoga de forma explícita com o seu manifesto-colagem de 1976. Ambos são visivelmente produto do período em que foram escritos, não se coibindo de, em liberdade - “ah a liberdade... / há liberdade" (Santos 1974: s.p.) -, tecer as suas críticas políticas mais duras à sociedade de consumo e à mercantilização da arte, combinando ambas num violento retrato satírico. Lemos no "manifesto à cidade": "há que não esquecer, na sociedade de consumo, que a produção de certos artistas é reclamada pelos frança, gonçalves, pernes \& cia., membros da a.i.c.a., como pastas dentífricas e sabonetes, segundo as modernas técnicas publicitárias...". Os mesmos críticos de arte que são nomeados num e noutro manifesto sofrem investidas do artista também, com especial destaque, na Carta ao crítico d'arte dr. rui mário gonçalves (1969), na exposição O bigode no espelho (1970), em duas publicações com o mesmo título (1975-76) e em da AICA laica lacaia (s.d. [1981]).

O conjunto de documentos agrupados sob o título da AICA laica lacaia ${ }^{26}$ dirige-se diretamente à Associação Internacional de Críticos de Arte (A.I.C.A.) e, de modo muito concreto, a Fernando Pernes, então recém-empossado presidente da secção portuguesa. 
Uma breve nota noticiosa dando conta dessa eleição é mesmo reproduzida (11) através de fotocópia com carimbo sobreposto onde se lê "a graça" e, atrás, em plano de fundo, um anúncio de jornal patenteia: “Ao Divino Espírito Santo - Agradeço graça concedida. Abílio". A jocosidade é presença assídua nas produções do artista. Nesta, em particular, há uma grande pluralidade de tons, que vão da sátira corrosiva à mais seca descrição. Já em 1970 escrevia Abílio, numa carta ao seu amigo Manuel Dias, reproduzida em da AICA laica lacaia:

[Fernando Pernes] é um dos mais famosos membros da secção portuguesa da Association Internationale des Critiques d'Art. Com os seus compadres Drs. José-Augusto França e Rui Mário Gonçalves são a guarda avançada e principais patrões da velha e nova crítica de Arte em Portugal de Aquém e Além Mar. Pois como toda a gente sabe, ligada a estes assuntos, têm na mão, em matéria de artes plásticas, alguns dos melhores jornais do país, as revistas especializadas e adequadas ao exercício das suas magníficas funções de mentores do Povo, uma galeria de Arte directamente e outras sob a sua paternalíssima simpatia, etc. e etc. ... (Santos 1970: 1)

Todos os textos que constituem da AICA laica lacaia são reproduções em fotocópia ${ }^{27}$ de artigos de opinião publicados por Abílio na imprensa periódica, sobre a situação da crítica de arte, a ligação do mundo da arte à banca, ao mundo empresarial e ao mecenato (através dos seus "mercenários", p. 4). Aí também se incluem reproduções de duas cartas: a primeira é aquela endereçada a Manuel Dias, referida acima, e a segunda uma "carta muito aberta à Sociedade Nacional de Belas Artes - Lisboa", com data própria de março de 1972, na qual Abílio-José Santos pede esclarecimentos sobre a exclusão de uma obra sua de exposição organizada por aquela instituição, ato que considera "vergonhoso porque arbitrário e ilegítimo" (Santos 1972: 3) e que, peremptoriamente, atribui ao "trio crítico" (leia-se: os três críticos de arte da A.I.C.A.), descrito como o "impagável conjunto vocal e plumitivo da nova crítica" que "são defendidos, propagandeados e promovidos [...] como os únicos fabricantes válidos e garantidos da arte moderna nacional." (ibidem).

Já noutra missiva, Carta ao crítico d'arte dr. rui mário gonçalves, ${ }^{28}$ Abílio denunciava a centralização de poder nestas personalidades, podendo ler-se em todos estes textos, mais do que uma crítica individualizada dos críticos de arte em questão, uma revolta contra os protocolos da institucionalização da arte e dos seus mecanismos de exercício de poder, as suas estratégias de inclusão e exclusão. ${ }^{29}$ Sem descurar a marcada dimensão interventiva e 
contestatária de toda a sua obra, aproxima-se ainda do manifesto ou texto panfletário um conjunto de outros trabalhos, como Carta a Vinicius (1969), Reza ao dólar (1982), Dia de pica boi (1983), 5 postais pra queimar (s.d.) ou Gente da poesis (1991), entre muitos dispersos publicados em revistas e mostrados em exposições de arte postal que são também exemplo da pluralidade de publicações do autor e da diversidade dos seus temas e focos de crítica.

Os textos de intervenção de Abílio-José Santos surgem, como atrás evidenciado, nos mais variados momentos do seu percurso. Resistem, por um lado, ao agrupamento por tipologias unívocas, problematizando o que é e não é um texto dito de intervenção. Não se confinam a temáticas ou alvos únicos, embora neste artigo se tenha optado por analisar a fundo apenas uma seleção dos textos mais diretamente relacionados com a crítica política do mundo da arte. De igual forma, não permitem a contenção em periodologias estanques. Em rigor, afirmações como a de que a partir do final da década de 1960 se verifica "uma inversão e o trabalho do autor passa a alinhar-se quase exclusivamente pela denúncia política" (Preto 2005: 183), também formulada de outros modos - "Abílio-José Santos abandona as experiências concretas voltando-se para a literalidade da propaganda, comprometendo a pesquisa estética pela veiculação de conteúdos ideológicos" (Preto 2005: 5) -, carecem de um fundo de verdade que apenas pode ser detetado de forma cabal à luz de uma análise em perspetiva que tenha em consideração o conjunto da obra do autor. António Preto chega mesmo a afirmar que Lidança é a única obra concretista do autor, adicionalmente caraterizando esse trabalho como apolítico:

\footnotetext{
Embora o autor possua uma vasta produção, que oscila entre as artes plásticas e a escrita, o facto de Lidança ser sistematicamente a única referência bibliográfica fornecida pelos poetas experimentais [nas suas publicações antológicas e documentais], justifica-se pela circunstância de essa ser uma das poucas obras de Abílio em que não se verifica uma subjugação da pesquisa estética à veiculação de conteúdos ideológicos. (Preto 2005: 183)
}

Embora seja indiscutível que este trabalho ocupa um lugar muito particular na produção do autor, será relevante verificar como, lançando uma mirada de conjunto sobre a sua obra artística, Lidança é o único trabalho de cariz concretista editado até à data de publicação nos livros e catálogos mencionadas por António Preto, ${ }^{30}$ pelo que não é de estranhar que apenas esse trabalho seja incluído nas listas bibliográficas. Já em obras 
coletivas posteriores, como se pode exemplificar através de Poemografias (1985), os biobibliodados não se cingirão à obra em apreço. A Antologia da Poesia Experimental Portuguesa (2004), outro marco imprescindível para uma leitura em perspetiva do fenómeno experimentalista, mostra isto de forma muito clara: dividida por décadas, de Abílio surgem na secção destinada aos anos 60 apenas três trabalhos, efetivamente provenientes de Lidança; contudo, outros poemas concretos e visuais aparecem nas secções dedicadas às restantes décadas cobertas pela antologia. Embora dispersa, a produção literária e artística de Abílio foi intensa ao longo de todos esses anos, como hoje o Arquivo Digital da PO.EX bem demonstra, ${ }^{31}$ com as lacunas naturais impostas por um trabalho artístico impossível de esgotar.

Para finalizar, argumente-se ainda que Lidança não é uma obra menos política do que outras, e com isto se contraria a ideia de que à experimentação formal se opõe a exploração temática, posto que, em realidade, não só estas duas dimensões se desenvolvem de modo simultâneo e recíproco, como fazem despontar uma terceira dimensão: a forte crítica sócio-política que, note-se, não "subjuga" nem "compromete" a artisticidade ou literariedade das obras, antes as expande e problematiza.

\section{Arte postal}

No início dos anos 80, Abílio iniciou uma profícua relação com vários artistas estrangeiros através do circuito de arte postal. Esse diálogo teve início aquando da sua participação na XVI Bienal de Arte de São Paulo (1981), a convite de Walter Zanini, precedida por duas outras exposições realizadas na mesma cidade brasileira, segundo revela o próprio artista:

Comecei a trabalhar em Arte Postal "oficialmente" por ter recebido convite do Prof. Dr. Walter Zanini para participar no núcleo de Arte Postal da XVI Bienal de S. Paulo. Atribuo este convite ao facto de ter conhecido o artista Artur Barrio, em 1977, quando realizou uma excelente exposição individual no Porto. Ficámos Amigos e por seu intermédio participei na exposição Poéticas Visuais realizada no Museu de Arte Contemporânea da Universidade de S. Paulo, pelo director Prof. Dr. W. Zanini. E também por trabalhos meus integrarem a representação portuguesa de Poesia na XIV Bienal de S. Paulo, nesse mesmo ano de 77. A inserção no catálogo de Arte Postal da XVI Bienal de S. Paulo dos 
endereços dos participantes trouxe-me os primeiros contactos de artistas doutros países. (Santos 1984: 1)

É ainda no mesmo ano de 1981 que Abílio-José Santos responde ao convite internacional que culmina na realização da exposição Poema Colectivo Revolución, com base num projeto de arte postal convocado pelo Colectivo 3, grupo composto por Aarón Flores, Araceli Zúñiga, Blanca Noval e César Espinosa, a partir da cidade do México. ${ }^{32}$ Com base no tema da "Revolução" - numa alusão à sublevação sandinista na Nicarágua então em curso mas procurando uma reflexão ampla sobre o assunto - o projeto consistiu na distribuição de uma folha com tamanho de carta apenas contendo uma moldura em branco para ser preenchida pelos artistas que a recebessem, depois assinada e devolvida aos proponentes do projeto, segundo as informações presentes em formato destacável na orla inferior da página. ${ }^{33}$ Realizaram-se duas exposições com as obras recebidas. A primeira, patente na Pinacoteca de la Universidad Autónoma de Puebla (1982), mostrou trabalhos de 130 artistas de 26 países, permanecendo aberta a convocatória ${ }^{34}$ que irá fazer com que aquando da exposição na Universidad Autónoma Metropolitana da Cidade do México (1983) o projeto se totalizasse já em cerca de quatro centenas de obras de artistas de mais de 40 países. AbílioJosé Santos participou neste projeto coletivo internacional e internacionalista ${ }^{35}$ tendo contribuído com doze trabalhos sobre o tema "Revolução", tão caro à sua obra. De Portugal, participaram ainda diversos artistas plásticos e intermédia, ${ }^{36}$ alguns deles presença assídua na rede de arte postal durante os anos 80 , e também autores trabalhos próximos da copy art, construídos com recurso a fotocópia e técnicas mistas, como Manuel Almeida e Sousa, Esther Olondriz e Emerenciano.

A revolução sandinista da Nicarágua, referida em vários trabalhos do $\operatorname{artista}^{37}$, não aparece diretamente nos trabalhos que Abílio apresenta nas exposições de Poema Colectivo Revolución. ${ }^{38}$ Há lugar para a revolução portuguesa (folhas 1 e 2) e o processo de transição democrática (folha 3, 5 e 6), a ditadura de Augusto Pinochet no Chile (folha não numerada), Ronald Reagan e as ligações dos Estados Unidos da América ao regime de Israel (folha não numerada) ou à conexão do então presidente dos E.U.A. à espionagem da C.I.A em Portugal (folha 4). Tudo isto sob a forma de fotocópias de artigos da imprensa portuguesa que o autor colige e faz circular internacionalmente. Mais interessantes ainda são os trabalhos 
criativos com os quais Abílio intervém neste projeto político de arte postal. Aí se incluem dois poemas visuais amplamente representados em antologias ("Revolução/Revelação", 1981; "Ovo, rua, revolução", 1981), mas também a menos conhecida proposta de "novas notas de um dólar" (1982), que se constitui enquanto crítica devastadora a Reagan e Frank Carlucci, embaixador dos E.U.A. em Portugal entre 1974 e 1978 e informador da C.I.A durante o período do Verão Quente. Aí se incluem também como alvo de crítica os “impagáveis soares, santos \& gama / donos do partido da partida do socialismo na gaveta" que, também eles, segundo esta "proposta ao cuidado do presidente reagan" receberão "pagamento de fretes democráticos de carluCíAdas" (Santos 1982a).

Em T'arrenego (1991), ${ }^{39}$ Abílio republica esta "proposta", lado a lado com vários textos-visuais realizados, segundo nota do autor, entre 1982 e 1985 expressamente para arte postal (Santos 1982b:). Se os três críticos de arte da A.I.C.A. são alvos individualizados mas simbólicos - das violentas sátiras do artista, na esfera política é a Ronald Reagan, presidente norte-americano à época, que é dada maior atenção. Conforme aí afirma o artista: "Reagan é o exemplar típico de certa classe política defensora da civilização cristã ocidental \& da sociedade de consumo, e sobretudo seu chefe nato, personificando a política hipócrita, prepotente, ingerente e belicosa dos u.s.a." (ibidem). Ao criticá-lo, critica a nova ordem mundial que inclui também os países "bafejados pela santa madre América imperialista do pistoleiro atómico do oeste nato, pentagonal \& ciático Al Reagan Capone, escancaradamente ou veladamente" (Santos 1984: 3). Serve a arte postal, argumenta, para a defesa da solidariedade, do diálogo e, não menos importante, dos grupos de pressão.

Data também deste período inicial do contacto de Abílio com artistas da rede de arte postal a sua ligação a Solidarte, um outro grupo mexicano, cujas linhas de ação cruzam a arte com a intervenção social, naquilo que hoje frequentemente se denomina como artivismo. Formado em 1982, Solidarte (Solidaridad Internacional por Arte Correo) foi um grupo de $\operatorname{artistas}^{40}$ reunidos em torno da reflexão social e prática interventiva através da rede de arte postal, sobretudo com o objetivo de denunciar os casos de perseguição, prisão e repressão política sobretudo em território latino-americano. As suas linhas de ação surgem sintetizadas no manifesto "Solidarte/México: Solidaridad Internacional": 
1) una producción artística y cultural que se opusiese a toda norma de imposición e intervención cultural, política y militar, 2) por la solidaridad y el apoyo a los movimientos de liberación de los pueblos oprimidos y clases trabajadoras, y 3) por el respeto a los derechos civiles y humanos y en favor de los movimientos por la paz y el desarme. (apud Nogueira 2014: 165)

O nome Solidarte/México só surge quando, noutros países, começam a aparecer grupos afins, como Solidarte/Brasil, Solidarte/Austrália, Solidarte/França, entre outros. Abílio é o fundador do núcleo Solidarte/Portugal - que vemos referido, por exemplo, nas palavras que carimbam um dos seus trabalhos de arte postal, "Homenagem a Mandela" $(1986)^{41}$ - e cuja pertença o artista narra com apreço - "Depois, como Você sabe, Amigo Guerrero, por ser um dos subscritores da carta, fui de novo honrado por artistas mexicanos, ao contactarem-me colectivamente para ser o centro de apoio da SOLIDARTE/MÉXICO." (Santos 1984: 3).

As vastas colaborações que Abílio desenvolve no âmbito da arte postal, como fuga às redes de informação institucionais e contraponto aos circuitos do mercado da arte, parecem demonstrar como este meio aberto, comunitário e deshierarquizado vem oferecer ao artista uma plataforma de comunicação que condiz na perfeição com o seu próprio posicionamento artístico e político, nomeadamente ao promover a comunicação livre e direta - não mediada por instituições e outros poderes ou capitais simbólicos -, daí resultando, nas palavras do próprio, um "estreitar [d]as relações de Fraternidade e Amizade entre artistas, mundialmente, através de processos de comunicação, criativos e experimentais, pelos Correios. Por isso os postalartistas contribuem para promover relações de Fraternidade e Amizade entre os Povos." (idem: 1). O internacionalismo do projeto da arte postal - criado, gerido e renegociado de forma contínua pelos próprios integrantes - constitui, por si mesmo, uma forma radical de ser e estar no mundo, quer esse "ser" esteja cerceado das suas liberdades individuais mais básicas ou esse "estar" seja realizado em plena liberdade. Em qualquer dos casos, como Abílio constata de forma tão lúcida quanto libertária, todo o empenho, participação e ação depende sempre dos sujeitos:

Creio que o desenvolvimento da Arte Postal não depende unicamente das condições sócio-culturais dos países. É evidente que num país onde em vez de amplas liberdades de criação, expressão, comunicação e reunião haja censura, violação da correspondência e outras formas de repressão 
criminosa todas as actividades dos cidadãos são muitíssimo dificultadas, prejudicando-os nos seus legítimos interesses individuais e colectivos, nacionais e internacionais. Mas a Arte Postal tem características para poder expandir-se sempre, mesmo nas condições sócio-culturais mais adversas. 0 seu desenvolvimento será difícil e até perigoso nuns países e, contrariamente, fácil e até estimulado noutros... Mas, essencialmente, depende do empenhamento dos postalartistas. (ibidem)

Ademais, a arte pode mesmo contribuir como instrumento crítico para agir no contexto societal, não apenas enquanto instrumento na cadeia de produção de discurso simbólico, mas, muitas vezes como elemento na cadeia micro-política da ação direta, neste sentido expandindo a conceção de Fredric Jameson segundo a qual "the production of aesthetic or narrative form is to be seen as an ideological act in its own right, with the function of inventing imaginary or formal 'solutions' to unresolvable social contradictions." (Jameson 2002: 64). Indo além da arte como interveniente simbólico pela criação de alternativas imaginárias, projetos de arte postal como os que Solidarte desenvolveu operacionalizam-se nos mesmos moldes daquilo que hoje leva o nome de tactical media, ${ }^{42}$ posto que ambos renegam o simbolismo da ação artística e reivindicam para si uma real dimensão interventiva através da combinação de arte, meios experimentais e ativismo político.

\section{Considerações finais}

Se as formas literárias experimentais foram sendo sistematicamente esquecidas nas grandes linhas de investigação dos estudos literários e da história da literatura em Portugal, seria hoje importante olhar para obras e autores como Abílio-José Santos, na suas filiações e afastamentos, para melhor entender o fenómeno literário da contemporaneidade sem incorrer no gesto acrítico da reprodução de lacunas pelo esquecimento ou alheamento. Num momento em que se intensificam, nas universidades, os estudos relacionados com alguns dos autores da poesia experimental portuguesa e, nas instituições artísticas e culturais, aumentam as exposições, publicações e debates sobre as suas obras, é relevante voltar o olhar também para aqueles autores que, um pouco à margem de sistemas e grupos, produziram uma obra de igual modo capaz de comunicar com o leitor do momento presente. 
A obra de Abílio, vista pelo prisma esboçado neste artigo, longe de firmar uma análise exaustiva da sua obra, técnicas, materiais e expressividades, permite vislumbrar uma poética de intervenção material (política, social, medial) que se desenvolve contribuindo para uma politização da estética e contra uma estetização da política. Fá-lo num sentido amplo, mas também naquele plano de pormenor em que se denunciam as injustiças que comandam o mundo, em geral, e o mundo da arte, em particular. Num tempo em que ganha terreno o manual de escrita criativa, com as suas fórmulas e normas únicas para o sucesso literário, julgo ser da maior importância voltar a olhar para as propostas de reescrita criativa manual de Abílio, revogadoras subversivas da normalização e da mesmidade através da sua micro-intervenção no mundo.

\section{NOTAS}

${ }^{1}$ É esta última que interessa analisar mais demoradamente neste artigo. Algumas das obras de Abílio-José Santos que se inscrevem neste núcleo estão disponíveis sob a forma de representantes digitais no Arquivo Digital da PO.EX (ed. Rui Torres, Universidade Fernando Pessoa). Ao longo do artigo será feita remissão $\mathrm{F} 75$ respetivas entradas sempre que tal seja possível e se justifique. Esta listagem não terá caráter exaustivo, por motivos de espaço e organização, pelo que se sugere a leitura exploratória do alargado número de obras do autor disponíveis no Arquivo a partir de https://po-ex.net/abilio.

${ }^{2}$ Aquando da primeira exposição individual de Abílio, de pintura e desenho, realizada na Galeria Divulgação, no Porto.

${ }^{3}$ Com linóleos de Maria Augusta, com quem Abílio colaborou extensamente. Trata-se de um desdobrável de grandes dimensões ( $49 \times 70 \mathrm{~cm}$ quando aberto) que apresenta uma sequência de onze poemas concretos que exploram as dimensões visuais e sonoras do signo verbal e a sua espacialização na página. A obra pode ser consultada no Arquivo Digital da PO.EX: https://po-ex.net/taxonomia/materialidades/planograficas/abiliolidanca/.

${ }^{4}$ Refira-se, a este respeito, o volume retrospetivo organizado por ambos (Hatherly / Melo e Castro 1981), mas também os contributos teóricos e documentais presentes nos estudos que exploram a relação do experimentalismo com as vanguardas (Melo e Castro 1965, 1976, 1984; Hatherly 1975, 1979) e nos estudos de 
arqueologia das formas experimentais, em particular no diálogo que estabelecem entre o experimentalismo e a tradição dos textos-visuais barrocos. Esta relação é evidenciada desde logo no trabalho seminal de Hatherly, $A$ Experiência do Prodígio: Bases teóricas e antologia de textos-visuais portugueses dos séculos XVII e XVIII (1983), livro ao qual se seguiram diversos volumes sobre a temática, culminando na recente publicação, a título póstumo, de Esperança e Desejo: Aspectos do pensamento utópico barroco (2018). Embora seja impossível apresentar um quadro concetual exaustivo nesta nota - quer por critérios de espaço, quer devido a uma certa instabilidade dos conceitos e definições da poesia experimental -, merecem ainda menção os breves mas expressivos ensaios de Salette Tavares e de António Aragão nos quais se relacionam vários momentos e expressões da história da literatura com a contemporaneidade do experimentalismo poético. Já Abílio, como deixou escrito pela sua própria mão, "talvez por ser um autodidacta insurrecto e panfletário nunca senti vocação para autor de textos teóricos sobre perspectivas de... não me ajeito! duma maneira geral não gosto das teorias que li ou televi nem dos gajos que as pariram!" (Santos 1985a: 107).

${ }^{5}$ Veja-se, no seu (COLAGE)Manifesto Vermelho, adiante analisado em detalhe, as palavras que redige a partir de um elogio aos ready-mades de Duchamp: "Igualado os objectos, igualou os seus autores e destruiu a pretensiosa superioridade do trabalho intelectual vulgar, normal. O trabalho do padeiro ou do sapateiro será menos importante do que o trabalho do pintor? * Ou do médico, ou do escritor, ou do ministro (mesmo P.S.)???..." (s.p.).

${ }^{6}$ Refira-se ainda a inclusão de trabalhos seus em algumas das mais importantes revistas experimentalistas internacionais, como Kaldron (n. 15, 1982; n. 18, 1984), Postextual (n. 1, 1986), Doc(k)s (n. 80-86, 1987), UNI/vers(;) (n. 2, 1988;), Bollettario (n. 4, 1991) e Dimensão (n.․ 21, 1991).

${ }^{7}$ Não só é impressionante o número de exposições em que participa como a diversidade de países em que obras suas foram expostas: Alemanha, Argentina, Áustria, Bélgica, Brasil, Canadá, Coreia do Sul, Espanha, Estados Unidos, Holanda, Israel, Itália, Japão, México, Nicarágua, Perú, Polónia, Portugal, República Dominicana e Suécia.

${ }^{8}$ Em organização conjunta com José Viale Moutinho, “O Poeta é um Fingidor - I Exposição Internacional de Arte Postal da A.J.H.L.P.", realizada em 1985 na sede da Associação de Jornalistas e Homens de Letras do Porto (da qual Abílio foi membro dos corpos gerentes e que, recentemente, recebeu a exposição retrospetiva de Abílio, O Guardador de Nada), exposição com réplica em 1986 na Escola Secundária n.o 2 de Santo Tirso; e "1. a Exposição Internacional de Arte Postal de Matosinhos", co-organizada em 1992 com César Figueiredo, artista de copy art portuense com quem Abílio colaborou em diversas ocasiões e principal responsável pela realização das mais relevantes exposições internacionais de arte postal realizadas no país.

${ }^{9}$ Sobre esta oficina diz Abílio: “Em Novembro de 1961 a Academia Dominguez Alvarez inaugurou uma oficina livre de gravura para D'Assumpção trabalhar na nossa cidade, continuando a realizar a sua obra gravada e para ensinar técnicas de gravura a todos que pretendessem aprender. Fomos alguns os que aprendemos os 
rudimentos de gravura com ele. E outros aprenderam depois connosco do que tínhamos aprendido, acrescido da experiência que todos juntos íamos adquirindo." (Santos 1970: 2)

${ }^{10} \mathrm{~A}$ escrita é aqui entendida num sentido amplo, inclusivo do ato de "ler" e de "ver", tal como comunica de forma feliz o verbo " $v(I) e r "$, jogo-neologismo criado por Abílio. Para além de aparecer em vários dos seus trabalhos de arte postal (como autocolante ou carimbo), v(l)er dá aí título a um conjunto de nove boletins do autor, bem como a um volume com o mesmo título (e igualmente não datado) que reúne, em folhas soltas numeradas e agrupadas em capa de cartolina, poemas concretos e visuais elaborados entre 1962 e 1983 , constituindo uma espécie de "obra completa" do autor até essa data.

${ }^{11} \mathrm{~A}$ este respeito refira-se a recente realização de um memorial performativo intitulado "De_composição e meta_morfose: a im_permanência da obra de Abílio-José Santos no Arquivo Digital da PO.EX". Esta iniciativa, organizada conjuntamente por Rui Torres, Sandra Guerreiro Dias e por mim, consistiu na apresentação de painel de comunicações no colóquio Besides the Screen, realizado na Maia a 5 e 6 de julho de 2018, atividade essa acompanhada, de forma interligada, por recurso digital a publicar futuramente no Arquivo Digital da PO.EX. Esta página será constituída por textos e apontamentos críticos (elaborados pelos investigadores mencionados), imagens fotográficas (narrativa visual, criada por Leonor Figueiredo, a propósito de visita à casa de Abílio na Maia tal como hoje a encontramos, vinte e seis anos após a sua morte ali permanecendo ainda o seu arquivo de artista) e vídeo (depoimentos de César Figueiredo, Isabel Camarinha, Bruno Carvalho e Estela Rodrigues sobre o autor e a sua obra).

${ }^{12}$ Os manifestos "lixarte" e "lixarte/2" estão disponíveis no Arquivo Digital da PO.EX através da reprodução dos panfletos de 1987 agrupados com o título "I e II Manifestos LIXARTE”, em edição do autor que inclui também vários poemas visuais e colagens relacionados com os manifestos: https://poex.net/taxonomia/materialidades/planograficas/abilio-manifestos-lixarte.

${ }^{13}$ Considere-se, a título de exemplo, uma vez mais, o seu (COLAGE)Manifesto Vermelho, nomeadamente no momento em que ali se afirma que "quando MARCEL DUCHAMP apresentou publicamente, a partir de 1914, os seus "READY MADE" - objectos prontos - realizou a MAIOR CRIAÇÃO ARTÍSTICA DE SEMPRE!!!" (s.p.); ou ainda quando inteiramente em letras garrafais o artista escreve: "Admiro Marcel Duchamp e creio que a arte moderna começa no movimento dada" (s.p).

${ }^{14}$ É possível consultar registos fotográficos de exemplares desta obra no Arquivo Digital da PO.EX em: https://po-ex.net/taxonomia/materialidades/tridimensionais/abilio-manifestos-lixarte-1-e-2/.

${ }^{15}$ Será interessante transpor para a obra de Abílio o que Manuel Portela afirma a propósito da obra objetual e “obgestual" de António Barros, também ele poeta experimental e artista intermédia, nomeadamente quando se sustenta que: “Ao participarem da semiótica social que produz identidade de classe e relações de poder, os 
objetos contêm múltiplas camadas semânticas que interpelam os indivíduos e determinam o exercício simbólico do poder." (Portela 2014: 189).

${ }^{16}$ Referidos como "emba(cu)lagem", num dos pacotes, ou "cu(emba)lagem", escrito noutro. Com efeito, tratase de paródicas colagens de traseiros em embalagens, conforme se pode ver no Arquivo Digital da PO.EX em: https://po-ex.net/taxonomia/materialidades/tridimensionais/abilio-ar-bento/.

${ }^{17}$ Obra editada em 1992 sob a forma de brochura e constante, na íntegra, do catálogo da V Bienal de Artes Plásticas da Festa do Avante (1985). Trabalhos desta série foram ainda reproduzidos parcialmente, de forma isolada ou em pequenos conjuntos, nos catálogos da IV Bienal Internacional de Cerveira (1984), Árvore 84 Exposição nacional de pequeno formato (1984) e I Bienal Internacional de Poesía Visual y Experimental (1985); nas revistas Kaldron (n.o 18, 1984), Sobreviver (n. 2, 1986), DOC(K)S (n.o 80-86, 1987), SCORE (n. 10, 1989) e Inter (n. 46, 1990); bem como no livro Poemografias (1985), editado por Fernando Aguiar e Silvestre Pestana, sendo também Aguiar o responsável pela organização de muitos dos números e dossiers incluídos nas revistas acima mencionadas, bem como de algumas das exposições em que Abílio participa.

${ }^{18} \mathrm{O}$ grupo é constituído por Abílio, Carlos Ferreira e Dias Santos e, sobre ele, Fátima Lambert refere o seguinte: “Breves escândalos e coloridas manifestações caracterizam a dinâmico do 'Grupo Vermelho', organizado em seu redor [de Abílio]. Integrava, ainda, Carlos Ferreira e Dias Santos, dando expansividade à sua personalidade irreverente, magnética e insaciada." (Lambert, 2003: s.p.)

${ }^{19} \mathrm{Vd}$. reprodução de cartaz próprio da obra na p. 41 da revista Artes Plásticas, n. 7-8, dezembro-janeiro de 1977.

${ }^{20}$ Embora se relacione com o Grupo Vermelho, até através do seu título, este manifesto-obra é assinado individualmente. Reprodução da matriz original deste trabalho está disponível no Arquivo Digital da PO.EX em: https://po-ex.net/taxonomia/materialidades/planograficas/abilio-jose-santos-colagem-manifesto-vermelho.

${ }^{21} \mathrm{O}$ texto que aqui se cita e o fragmento em que se insere no manifesto-colagem é recorte de "arte e liberdade".

${ }^{22}$ Intervenção manuscrita no manifesto. No texto de origem ("arte e liberdade"), lia-se apenas: "esse nível é atingido por artistas. os artistas existem." (Santos s.d. [197-]).

${ }^{23} \mathrm{O}$ sujeito da frase é, no contexto original ("manifesto à cidade"), não "o artista revolucionário" mas "a sociedade cooperativa de actividades artísticas 'árvore'".

${ }^{24}$ Inscrição sob a forma de escrita caligráfica. Não presente em texto anterior, note-se que as palavras do autor estão perfeitamente sincronizadas com o tempo da sua escrita, sendo marcadas por uma certa desilusão pósPREC que toma o lugar da expetativa otimista presente no manifesto de 1974. 
${ }^{25}$ De seu título completo "manifesto à cidade de um manifesto à cidade dum trabalhador fabril-técnico de desenho artista autodidacta amador dadaísta" (1974), incluído no panfleto desdobrável Despertador, disponível no Arquivo Digital da PO.EX em: https://po-ex.net/taxonomia/materialidades/planograficas/abiliojose-santos-despertador/.

${ }^{26}$ Disponível no Arquivo Digital da PO.EX em: https://po-ex.net/taxonomia/materialidades/planograficas/abiliojose-santos-da-aica-laica-lacaia/.

${ }^{27}$ Com imposição do carimbo "ARTE POSTAL" que encontramos em muitos dos trabalhos do artista.

${ }^{28}$ Disponível no Arquivo Digital da PO.EX em: https://po-ex.net/taxonomia/materialidades/planograficas/abiliojose-santos-carta-ao-critico-d-arte-dr-rui-mario-goncalves/.

${ }^{29}$ Exclusão até num sentido literal, como foi o caso da não aceitação de obra de Abílio na exposição do Banco Português do Atlântico, bloqueado por um júri constituído por elementos da A.I.C.A. A obra rejeitada, O bigode no espelho (1968), é uma assemblagem de dimensões variáveis constituída por tufo de cabelo colado sobre espelho emoldurado. A obra pertence à coleção da família do artista e, à semelhança de outros trabalhos, encontra-se depositada na Fundação de Serralves - Museu de Arte Contemporânea, no Porto. Abílio realizou uma exposição homónima em 1970 na Galeria Árvore, no Porto, e, também com o mesmo título, publicou dois folhetos em 1975 e 1976, sempre apontando para O bigode no espelho como "um símbolo e uma denúncia" (lê-se na capa do n.ㅇ 1).

${ }^{30} \mathrm{O}$ autor reporta-se à Antologia da Poesia Concreta em Portugal (1973), ao catálogo da XIV Bienal de São Paulo (1977), ao catálogo de PO.EX/80 (1980) e ao volume PO.EX: Textos teóricos e documentais da poesia experimental portuguesa (1981).

${ }^{31}$ De resto, a sistematização realizada neste artigo parte das obras disponíveis no referido Arquivo bem como de uma expansão dos dados biobibliográficos de Abílio apensados ao artigo de Eunice Ribeiro (2014).

${ }^{32}$ Uma relação de mútuo apreço manter-se-á por vários anos com César Espinosa, a quem Abílio dedica o curto folheto anticolonialista com o longo título Crónica de escárnio \& mal dizer das Descobertas quinhentos anos depois ou nas mesmas mãos as cruzes \& noutras mãos as espadas (1992), consultável no Arquivo Digital da PO.EX em: https://po-ex.net/taxonomia/materialidades/planograficas/abilio-jose-santos-cronica-de-escarnioe-maldizer-das-descobertas/. Espinosa publicou em 1983, na série de publicações editada pelo Colectivo 3 sob o título Poesia/Visual-Experimental/Poetry, um breve opúsculo com oito poemas visuais e concretos de Abílio. César Espinosa e Araceli Zuñiga, organizadores das Bienais de Poesia Experimental e Visual do México, em cujas exposições o artista português participou por diversas ocasiões, dedicaram a quinta edição da bienal, de 1996, à memória de Abílio.

${ }^{33}$ Um exemplar da folha modelo é reproduzido em Marcin (2013). 
${ }^{34}$ Aliás, vai ser reforçada, conforme comprova o convite disponível no sítio web do Artpool Art Research Center: http://www.artpool.hu/MailArt/chrono/1982/Poema.html\#Call.

${ }^{35}$ Escrevem César Espinosa e Araceli Zúñiga no catálogo da exposição realizada na Universidad Autónoma Metropolitana: “Acreditamos que, enquanto entidade semiótica, o Poema Colectivo Revolución reúne um mosaico ideológico internacional, cujas variantes poderiam ser usadas para mapear critérios e estratégias para um internacionalismo artístico e cultural. Hoje no México, sustentamos que a poesia visual pode significar um ato revolucionário, tanto em termos estéticos quanto para empoderar as capacidades significadoras da maioria de trabalhadores com seus gráficos, com a circulação obtida e também na comunicação popular." (apud Nogueira 2017: s.p.).

${ }^{36} \mathrm{~A}$ saber: Albuquerque Mendes, António Olaio, Armando Azevedo, Elisabete Mileu, Manoel Barbosa e Pedro Cabrita Reis.

${ }^{37} \mathrm{Vd}$. por exemplo, em T'arrenego, o poema "glória aos sandinistas", com dedicatória em epígrafe: "para o mexicano césar espinosa / e os outros amigos do colectivo 3 / e da solidarte - solidariedade internacional por arte correio".

${ }^{38}$ Vejam-se os trabalhos de Abílio digitalizados na plataforma Post e sítio web do MoMA em: http://post.at.moma.org/themes/10-poema-colectivo-revolucion-and-the-international-mail-art-network (clicar em "Portugal").

${ }^{39}$ Disponível no Arquivo Digital da PO.EX em: https://po-ex.net/taxonomia/materialidades/planograficas/abiliotarrenego-tio-sam/.

${ }^{40}$ Coletivo constituído por Aarón Flores, Blanca Noval, Carmen Medina, Jesús Romeo Galdámez e Mauricio Guerrero.

${ }^{41}$ Vd. p. 2 da obra no Arquivo Digital da PO.EX em: https://po-ex.net/taxonomia/materialidades/ planograficas/abilio-homenagem-a-mandela/ (imagem 4/8 da galeria).

${ }^{42}$ No texto seminal "The ABC of Tactical Media" definida nos seguintes termos: "Tactical Media are what happens when the cheap 'do it yourself' media, made possible by the revolution in consumer electronics and expanded forms of distribution (from public access cable to the internet) are exploited by groups and individuals who feel aggrieved by or excluded from the wider culture." (Garcia / Lovink 1997: s.p.). 


\section{Bibliografia}

Álvaro, Egídio (1977a), "Presença - exposição/encontro", Artes Plásticas, n. 7-8, dezembrojaneiro, 22.

-- (1977b), “Debates”, Artes Plásticas, n. 7-8, dezembro-janeiro, 54-59.

Azevedo, Cristina de (1985), "O encontro de dois polos distintos", in Santos, Abílio-José, Poéticas Visuais [catálogo], Lisboa, Atelier 15, s.p. Disponível em: https://poex.net/taxonomia/materialidades/planograficas/abilio-jose-santos-poeticas-visuais/ (último acesso em 28-04-2018).

Compagnon, Antoine (1996), O Trabalho da Citação, tradução de Cleonice Mourão, Belo Horizonte, Editora UFMG. [1. a ed. 1979]

Dias, Sandra Guerreiro (2016), O Corpo como Texto: Poesia, performance e experimentalismo nos anos 80 em Portugal [tese de doutoramento], Faculdade de Letras da Universidade de Coimbra. Disponível em: http://hdl.handle.net/10316/29608 (último acesso em 01-04-2018). Dworkin, Craig Douglas (ed.) (2003), Reading the Illegible (Avant-garde and Modernism Studies), Evanston, Northwestern University Press.

Faria, Óscar (2001), "Duas décadas de arte no Porto", Público (em linha), 25 de janeiro, https://www.publico.pt/2001/01/25/jornal/duas-decadas-de-arte-no-porto-154039 (último acesso em 23-04-2018).

Garcia, David / Geert Lovink (1997), "The ABC of Tactical Media", nettime mailinglist, 16 de maio. Disponível em: http://www.nettime.org/Lists-Archives/nettime-l9705/msg00096.html [versão de arquivo] (último acesso em 28-04-2018).

Hatherly, Ana (1975), A Reinvenção da Leitura: Breve ensaio crítico seguido de 19 textos visuais, Lisboa, Editorial Futura.

-- (1979), O Espaço Crítico: do simbolismo à vanguarda, Lisboa, Caminho.

Hatherly, Ana / E. M. de Melo e Castro (orgs.) (1981), PO.EX: Textos teóricos e documentos da poesia experimental portuguesa, Lisboa, Moraes Editores. 
Jameson, Fredric (2002), The Political Unconscious: Narrative as a socially symbolic act, London / New York, Routledge. [1. a ed. 1982]

Lambert, Fátima (2003), “Olhares e escritas na arte portuguesa desde 1960", in Homem, Rui Carvalho / Fátima Lambert (orgs.), Olhares e escritas na arte portuguesa desde 1960 [catálogo], Porto, Galeria do Palácio.

Lambert, Fátima / João Fernandes (2001), "Porto 60/70: Os artistas e a cidade”, in Lambert, Fátima / João Fernandes (orgs.), Porto 60/70: Os Artistas e a Cidade [catálogo], Porto, Edições Asa, 15-40.

Marcin, Mauricio (2013), "Sobre la propiedad privada y el amor: Poema Colectivo Revolución", Post (em linha), http://post.at.moma.org/content_items/360-sobre-lapropiedad-privada-y-el-amor-poema-colectivo-revolucion (último acesso em 27-04-2018).

Melo e Castro, E. M. de (1965), A Proposição 2.01: Poesia experimental, Lisboa, Ulisseia.

-- (1976), Dialéctica das Vanguardas, Lisboa, Livros Horizonte.

-- (1984) Projecto: Poesia, Lisboa, Imprensa Nacional - Casa da Moeda.

Metello, Verónica (2009), Focos de Intensidade / Linhas de Abertura. A ativação do mecanismo performance 1961-1979 [tese de mestrado], Faculdade de Ciências Sociais e Humanas da Universidade Nova de Lisboa.

Nogueira, Fernanda (2014), “Internacionalismos" [verbete], in Tapia, Mabel / Jaime Vindel / Fernanda Carvajal / André Mesquita... [et. al.] (orgs.), Perder la Forma Humana. Una imagen sísmica de los años ochenta en América Latina, Sáenz Peña, Universidad Nacional de Tres de Febrero / Museo Nacional Centro de Arte Reina Sofía, 160-170.

-- (2017), “Revolução: um poema coletivo. Potências poético-políticas da rede de arte postal", A Bolha (em linha), 31 de julho, https://abolha.com/2017/07/31/revolucao-umpoema-coletivo/ (último acesso em 23-04-2018).

Perloff, Marjorie (2003), The Futurist Moment: Avant-garde, avant guerre, and the language of rupture, Chicago, University of Chicago Press. 
Pimenta, Alberto (1988), “Que poesia exprim(o)mental?”, in Monteiro, Manuel Hermínio (org.), Um Século de Poesia. A Phala - edição especial, Lisboa, Assírio \& Alvim, 144-149.

Portela, Manuel (2014), "Como fazer poemas com objetos", in Rui Torres (org.), Poesia Experimental Portuguesa: Contextos, ensaios, entrevistas, metodologias, Porto, Edições Universidade Fernando Pessoa, 189-191. Disponível em: https://poex.net/taxonomia/transtextualidades/metatextualidades-alografas/manuel-portela-comofazer-poemas-com-objetos/ (último acesso em 12-04-2018).

Preto, António (2005), A Poesia Experimental Portuguesa: 1960-1980 [tese de mestrado], Faculdade de Belas Artes da Universidade de Lisboa.

Ribeiro, Eunice (2014), "Abílio: As manufacturas da escrita", in Rui Torres (org.), Poesia Experimental Portuguesa: Contextos, ensaios, entrevistas, metodologias, Porto, Edições Universidade Fernando Pessoa, 9-31. Disponível em: https://poex.net/taxonomia/transtextualidades/metatextualidades-alografas/eunice-ribeiro-abilio-asmanufacturas-da-escrita/ (último acesso em 23-02-2018). [1995 - Diacrítica, n.ํ 10, 205-224] Rodrigues, Severino (1959), Abílio apresentado por Severino Rodrigues, Porto, edição de Abílio-José Santos / Livros da Sereia. Disponível em: https://poex.net/taxonomia/transtextualidades/metatextualidades-alografas/severino-rodrigues-oabilio/ (último acesso em 27-04-2018).

Santos, Abílio-José (1968), "[edital]", texto patente na exposição na Galeria Alvarez, maio de 1968, Porto. Disponível em: https://po-ex.net/taxonomia/transtextualidades/ metatextualidades-autografas/abilio-jose-santos-edital/ (último acesso em 03-05-2018).

-- (1970), Carta para Manuel Dias, in da AICA laica lacaia (s.d [1981)], S.L., edição do autor, 12. Disponível em: https://po-ex.net/taxonomia/materialidades/planograficas/abilio-josesantos-da-aica-laica-lacaia (último acesso em 26-04-2018).

-- (1972), "Carta muito aberta à Sociedade Nacional de Belas Artes - Lisboa", in da AICA laica lacaia (s.d [1981)], S.L., edição do autor, 3. Disponível em: https://poex.net/taxonomia/materialidades/planograficas/abilio-jose-santos-da-aica-laica-lacaia (último acesso em 26-04-2018). 
-- (s.d. [197-]), “arte e liberdade". Disponível em: https://poex.net/taxonomia/transtextualidades/metatextualidades-autografas/abilio-arte-e-liberdade/ (último acesso em 01-05-2018).

-- (1974), “manifesto à cidade". Disponível em: https://poex.net/taxonomia/materialidades/planograficas/abilio-manifesto-a-cidade/ (último acesso em 01-05-2018).

-- (1976), (COLAGE)Manifesto Vermelho. Disponível em: https://poex.net/taxonomia/materialidades/planograficas/abilio-jose-santos-colagem-manifestovermelho/ (último acesso em 01-05-2018).

-- (1982a), "novas notas de um dólar", in T'arrenego (1991), Maia, edição do autor. Disponível em: https://po-ex.net/taxonomia/materialidades/planograficas/abilio-tarrenegotio-sam/ (último acesso em 30-04-2018).

-- (1982b), Ficha técnica, in T'arrenego (1991), Maia, edição do autor. Disponível em: https://po-ex.net/taxonomia/materialidades/planograficas/abilio-tarrenego-tio-sam/ (último acesso em 30-04-2018).

-- (1984), Depoimento endereçado a Mauricio Guerrero - "[Pratico Arte Postal]". Disponível em: https://po-ex.net/taxonomia/transtextualidades/metatextualidades-autografas/abiliopratico-arte-postal/ (último acesso em 26-04-2018).

-- (1985a), "[Caríssimos senhores]", in Aguiar, Fernando / Silvestre Pestana (orgs.), Poemografias: Perspectivas da Poesia Visual Portuguesa, Lisboa, Ulmeiro, 107-108. Disponível em: https://po-ex.net/taxonomia/transtextualidades/metatextualidadesautografas/abilio-carissimos-senhores/ (último acesso em 22-03-2018).

-- (1985b), Poéticas Visuais [catálogo], Lisboa, Atelier 15. Disponível em: https://poex.net/taxonomia/materialidades/planograficas/abilio-jose-santos-poeticas-visuais/ (último acesso em 28-04-2018).

-- (1987a), "manifesto lixarte", in I e II Manifestos LIXARTE, Maia, edição do autor. Disponível em: https://po-ex.net/taxonomia/materialidades/planograficas/abilio-manifestos-lixarte/ (último acesso em 26-04-2018). 
-- (1987b), "manifesto lixarte/2, in I e II Manifestos LIXARTE, Maia, edição do autor. Disponível em: https://po-ex.net/taxonomia/materialidades/planograficas/abiliomanifestos-lixarte/ (último acesso em 26-04-2018).

Torres, Rui (2014), "Visualidade e expressividade material na poesia experimental portuguesa", in Rui Torres (org.), Poesia Experimental Portuguesa: Contextos, ensaios, entrevistas, metodologias, Porto, Edições Universidade Fernando Pessoa, 9-31. Disponível em: http://po-ex.net/taxonomia/transtextualidades/metatextualidades-alografas/rui-torresvisualidade-e-expressividade-material-na-poesia-experimental-portuguesa (último acesso em 13-03-2018).

Torres, Rui / Bruno Ministro (2016), Apresentação e enquadramento de Lidança, 18 de setembro, Porto, Gato Vadio.

Bruno Ministro é doutorando em Materialidades da Literatura na Faculdade de Letras da Universidade de Coimbra. Este trabalho foi desenvolvido no âmbito da Bolsa de Doutoramento FCT com a referência PD/BD/105707/2014. Gostaria de expressar o meu agradecimento a Rui Torres (Arquivo Digital da PO.EX) e Bruno Carvalho (sobrinho de AbílioJosé Santos) pelos esclarecimentos e auxílio prestado durante a redação deste artigo, bem como pela autorização para reproduzir as imagens que acompanham o texto. 